Old Dominion University

ODU Digital Commons

2020

Does Starting School Before Labor Day Affect High School

Retention and Graduation: Evidence From Virginia's Kings

Dominion Law

Timothy M. Komarek

Old Dominion University, tkomarek@odu.edu

Jay K. Walker

Old Dominion University, j1walker@odu.edu

Follow this and additional works at: https://digitalcommons.odu.edu/economics_facpubs

Part of the Economic Theory Commons, Education Economics Commons, and the Public Economics Commons

Original Publication Citation

Komarek, T. M., \& Walker, J. K. (2020). Does starting school before Labor Day affect high school retention and graduation: Evidence from Virginia's Kings Dominion Law. SSRN eLibrary, 12 pp. doi:10.2139/ ssrn.3607569

This Article is brought to you for free and open access by the Department of Economics at ODU Digital Commons. It has been accepted for inclusion in Economics Faculty Publications by an authorized administrator of ODU Digital Commons. For more information, please contact digitalcommons@odu.edu. 


\title{
Does Starting School Before Labor Day Affect High School Retention and Graduation: Evidence from Virginia's Kings Dominion Law
}

\author{
Tim Komarek* and Jay K. Walker ${ }^{\dagger}$
}

May 21, 2020

\begin{abstract}
Several states have required K-12 public schools to start after Labor Day in an effort to aid the tourism and hospitality industry. However, little is known about how these policies impact educational outcomes. We examine the impact of Virginia's post-Labor Day school start law on high school retention and graduation rates. We use a differencein-differences model to exploit exogenous variation in school division start dates. Our results show small differences of up to three weeks have little effect on high school dropout and graduation rates. Our findings inform the debate on post-Labor Day school start laws and compulsory attendance age cutoff laws.
\end{abstract}

Keywords: Labor Day School Start; Graduation Rates; Retention Rates; Age effects

JEL classification codes: I20, I21, J29

\footnotetext{
*Assistant Professor of Economics, Department of Economics, Old Dominion University, Constant Hall 2023, Norfolk, VA 23529, USA. Phone: 1-757-683-4534. Email: tkomarek@odu.edu.

$\dagger$ Assistant Professor of Economics, Department of Economics, Old Dominion University, Constant Hall 2048, Norfolk, VA 23529, USA. Phone: 1-757-683-3577. Email: j1walker@odu.edu
} 


\section{Introduction}

There has been renewed interest among policymakers to start the K-12 school year after Labor Day. In 2018, legislatures in Georgia, Maryland, Missouri, New Hampshire, Ohio, Rhode Island and West Virginia debated making it a requirement for all public schools. States see starting K-12 schools later in the summer, not as a strategy to boost student outcomes, but as a way to aid the hospitality and tourism industries. The topic is controversial and pits educators, parents and economic interests against each other. The tension between these interests recently played out in Maryland. In 2016, Maryland's Governor, citing support for the tourism industry ${ }^{1}$, used an executive order to force all schools to start after Labor Day. However, after pressure from educators and parents the legislature overturned the executive order just three years later (Broadwater and Richman, 2019).

Despite the fervor of the debate, little is known about the impact on educational outcomes from requiring schools to start after Labor Day. The closest related literature examines the impact of compulsory attendances laws and shows that increasing the age for compulsory attendance increases educational attainment (see i.e. Dobkin and Ferreira (2010) or Hemelt and Rosen (2016))

In this note, we examine how Virginia's post-Labor Day school start law impacted retention and graduation rates for several demographic groups. The law, colloquially referred to as the Kings Dominion law ${ }^{2}$ after an amusement park near Richmond, VA that originally lobbied for it, was passed in 1986 and repealed in 2019. It required Virginia schools to begin after Labor Day unless they met specific conditions for a waiver. Schools qualified for a waiver either based on closings due to inclement weather ${ }^{3}$ or offering experimental education programs. Like other states, Virginia requires a minimum amount of school contact time, ${ }^{4}$

\footnotetext{
${ }^{1}$ http://comptroller.marylandtaxes.gov/Public_Services/Agency_Information/Office_of_the_ Comptroller/Comptroller_Initiatives/Schools_After_Labor_Day_BRE_Study.pdf

${ }^{2}$ For more detailed discussion of the Virginia policy see Dragas (2018).

${ }^{3}$ For an inclement weather waiver a schools division must have closed an average of eight days per year during any five of the last ten years because of severe weather conditions, power failures or other emergency situations.

${ }^{4} 180$ calendar days or 990 instructional hours for grades one through twelve.
} 
as shown in Figure 1 creates notable differences in start and end dates based on a school's waiver status.

Furthermore, Virginia's compulsory attendance law requires children that turn 5 by October 1st to start kindergarten and remain in school until they reach $18 .{ }^{5}$ Thus, the oldest student in any individual cohort could withdraw from high school starting on October 1st, less than one full month into their senior year if the first day of school was after Labor Day.

We use Virginia's state-level policy to estimate the effect of a school's start date on retention and graduation rates for several demographic groups. The policy provides arguably exogenous variation in school start dates and the length of time until students reach the compulsory attendance age based on historical local weather conditions. Our difference-indifferences estimates suggest that small changes in school start dates do not impact school retention and graduation rates, however we provide some evidence that earlier school start dates (in our sample, three weeks or greater before Labor Day) impact retention and graduation. Our results help inform the broader literatures on school cutoff dates and compulsory schooling, offering some suggestive evidence that by starting the school year earlier and forcing the date when students reach the age of majority later in the academic year it may be associated with greater graduation and retention.

\section{Data and Estimation Strategy}

We use data from the Virginia Department of Education on school start dates along with graduation and dropout rates for the 133 school divisions in Virginia covering the 2006-2007 through 2016-2017 academic years. We also incorporate data on the local unemployment rate from the Bureau of Labor Statistics and education spending from the Virginia Auditor of Public Accounts Local Government Comparative Reports. In our sample 50 of the total 133 school divisions changed their start date relative to Labor Day. Figure 2 shows the

\footnotetext{
${ }^{5}$ Source: Code of Virginia, $\S 22.1-199$. Kindergarten programs suitable for certain children. Available online here: https://law.lis.virginia.gov/vacode/title22.1/chapter13/section22.1-199/.
} 
percentage of school divisions with a Pre-Labor Day start for each academic year as well as the number of school divisions that switched from a Pre to Post start (or vice versa). Over the sample, the percentage of schools opting for a Pre-Labor Day start increased from 51.9 percent in the 2007-2008 academic year to 62.8 percent in the 2016-2017 academic year.

We focus on two educational outcomes: the four-year on-time graduation rate $^{6}$ and the dropout rate. Table 1 compares the graduation and dropout rates by Labor Day start status across different socio-economic, gender, and minority groups. We use simple t-tests to show the differences in the means between both school start dates. Most groups show lower ontime graduation rates and higher dropout rates in school divisions that start after Labor Day.

Our empirical strategy uses panel data techniques to leverage the variation in both the timing and location of changes in school start dates. We use a 'difference-in-differences' approach to identify the effect on educational outcomes using the following model:

$$
Y_{d t}=\sum_{i=1}^{n} \beta_{i} L a b o r D a y_{d t}+X_{d t} \Theta+\alpha_{d}+\delta_{t}+\lambda_{d} * \text { Time }+\zeta_{d} * T i m e^{2}+\epsilon_{d t}
$$

Where $Y$ is the outcome variable (on-time graduation and dropout rate) for school division $d$ in academic year $t$. LaborDay is an indicator for the number of weeks a school starts prior to Labor Day. The vector $X_{d t}$ contains the local unemployment rate in January of the graduation year and real per pupil education spending. ${ }^{7}$ Using panel data allows us to control for several different forms of unobserved heterogeneity that could potentially confound estimates. $\alpha_{d}$ are school division fixed effects that control for observable and unobservable differences across divisions that are constant over time. The time fixed effect $\delta_{t}$ controls for

\footnotetext{
${ }^{6}$ The on-time graduation rate captures student progress through high school in the "normal" amount of time.

${ }^{7}$ Due to data availability for per pupil educational spending and local unemployment rate being limited by specific geographical boundaries in Virginia, we chose to exclude two school divisions from the main analysis: Colonial Beach and West Point. Results are consistent as those shown below when included and not controlling for spending nor unemployment.
} 
common shocks that affect in all divisions over time. We also use school division specific linear and quadratic trends, $\lambda_{d} *$ Time and $\zeta_{d} * T i m e^{2}$, to flexibly account for division specific time-varying heterogeneity.

This empirical model is equivalent to difference-in-difference models that use interactions between Labor Day start dates and time indicators (Angrist and Pischke, 2008). Finally, we cluster standard errors at the division level in the event of systematic within group relationships at the division level (Arellano, 1987).

\section{Results and Discussion}

Table 2 shows estimates on the relationship between the number of weeks school divisions start before Labor Day with drop out and on-time graduation rates. The top panel examines on-time graduation while the bottom panel displays results on the dropout rate. The results are delineated by demographic group and fixed effect strategy i.e. controlling for division linear and quadratic time trends.

In the top panel the full sample in columns (1) and (2) shows weak evidence that starting the school year earlier in the summer impacts on-time graduation. Only starting school three weeks or earlier before Labor Day is positive and marginally significant (10 percent level). In particular, the on-time graduation rate is $1.8 \%$ higher for students in school divisions that start three weeks or more before labor compared to those that start after Labor Day. Columns (3)-(6) show the results across genders. The estimates in column (4) suggest increases in male on-time graduation are driving the positive effect in the full sample. Furthermore, we do not find statistically significant estimates for on-time graduation for any demographic group (Black, Asian, Hispanic, and Economically Disadvantaged ${ }^{8}$ ).

The bottom panel displays the estimates of a pre-Labor Day start date on dropout rates.

\footnotetext{
8"Economically disadvantaged is defined as 1) eligible for Free/Reduced Meals, or 2) receives TANF, or 3) eligible for Medicaid, or 4) identified as either migrant or experiencing homelessness. For more information see: http://www.doe.virginia.gov/statistics_reports/research_data/data_elements.shtml.
} 
Again, we do not find statistically significant results for school divisions starting within two weeks of Labor Day for the full sample or any demographic group. However, in column (2) with district quadratic time trends shows a negative and statistically significant effect at the 5 percent level. This suggests that starting the school year three or more weeks before labor day could lower dropout rates. In a similar vein as on-time graduation rates, the break down by different demographic groups suggests that this result is driven by males. Column (4) shows that male dropout rates decline by $2.3 \%$, while female dropout rates declined by $1.8 \%$. The remaining demographic groups have negative but not statistically significant effects at conventional levels.

We leverage a natural experiment where schools most often qualified for a waiver to start before Labor Day based on closings due to inclement weather. We use division linear and quadratic time trends to control for time varying heterogeneity. However, the differencein-differences model, shown in equation 1, hinges on parallel pre-existing trends. We test for pre-existing trend by estimating falsification tests shown in Table $3 .^{9}$ Our falsification tests estimate the model in equation (1) with the Labor Day indicator variable shifted ahead 2 years before a change actually took place. Thus, using division and year fixed effects, contemporaneous indicators of the number of weeks school start before Labor Day should predict the relationship between the school start date and educational outcomes, if there is one, while leads prior to the school start change should not. Each model in Table 3 includes all of the control variables as well as division and year fixed effects. The pre-Labor Day indicators are not significant at the $10 \%$ level for any of the demographic groups, suggesting that our results are not due to pre-existing trends.

\footnotetext{
${ }^{9}$ For more information on placebo regression see Bertrand et al. (2004).
} 


\section{Conclusions}

According to the Education Commission of the States, the majority of states allow school divisions to determine their own start dates. However, several states provide some division control on the start of the academic year within specified ranges, such as Aug. 15-31, and a handful of others mandate some or all of their schools to start after Labor Day. Anecdotal evidence from several states, including Michigan, Maryland and Virginia, suggest that the decision to delay the start of K-12 schools until after Labor Day appears driven by economic rather than educational interests.

In this research note, we incorporate plausibly exogenous variation in school starting dates relative to Labor Day to estimate its effect on student drop out and on-time graduation rates. To the best our knowledge, this the first paper to leverage this type of variation to study educational outcomes. Our results show some evidence that dropout rates increase on-time graduation and decrease dropout rates, but only for school divisions that start 3 or more weeks before Labor Day. These results appear to be driven by male students. Furthermore, starting class before Labor Day does not have a statistically significant effect on disadvantaged demographic groups.

Our proposed mechanism suggests that earlier school start dates result in students hitting compulsory school cutoff age (turning 18 years old) later in their senior year. This could then change the cost-benefit calculation on the margin for some to continue attending school. Thus, our findings inform both the literature on school start dates as well as work school cutoff dates and compulsory schooling laws. 


\section{References}

Angrist, J. D. and Pischke, J.-S. (2008). Mostly harmless econometrics: An empiricist's companion. Princeton university press.

Arellano, M. (1987). Practitioners'corner: Computing robust standard errors for withingroups estimators. Oxford Bulletin of Economics and Statistics, 49(4):431-434.

Bertrand, M., Duflo, E., and Mullainathan, S. (2004). How much should we trust differencesin-differences estimates? The Quarterly Journal of Economics, 119(1):249-275.

Broadwater, L. and Richman, T. (2019). Maryland legislators override veto, allow school to start pre-labor day; districts not rushing to shift schedules. Carroll County Times. https://www.carrollcountytimes.com/news/government/bs-md-labor-day-vetooverride-20190329-story.html.

Dobkin, C. and Ferreira, F. (2010). Do school entry laws affect educational attainment and labor market outcomes? Economics of Education Review, 29(1):40-54.

Dragas Center for Economic Analysis and Policy (2018). Much Ado About Nothing? Virginia's "Kings Dominion" Law. 2018 State of the Commonwealth Report.

Hemelt, S. W. and Rosen, R. B. (2016). School entry, compulsory schooling, and human capital accumulation: evidence from michigan. The BE Journal of Economic Analysis \& Policy, 16(4). 


\section{Tables}

Table 1. 2007-2008 to 2016-2017 Academic Year: On-time graduation rates and dropout rates by Pre-Labor Day start status

\begin{tabular}{|c|c|c|c|c|}
\hline & $\begin{array}{c}\text { Post Labor } \\
\text { Day Start }\end{array}$ & $\begin{array}{l}\text { Pre-Labor } \\
\text { Day Start }\end{array}$ & $\begin{array}{l}\text { Difference } \\
\text { (Post-Pre) }\end{array}$ & p-value \\
\hline \multicolumn{5}{|l|}{ On-time graduation rate } \\
\hline All students & 86.0 & 87.9 & $-1.8 \mathrm{pp}$ & 0.00 \\
\hline Economically Disadvantaged & 79.7 & 81.9 & $-2.3 \mathrm{pp}$ & 0.00 \\
\hline \multicolumn{5}{|l|}{ By minority status } \\
\hline Asian & 92.8 & 93.4 & $-0.6 \mathrm{pp}$ & 0.52 \\
\hline Black & 84.1 & 85.4 & $-1.3 \mathrm{pp}$ & 0.01 \\
\hline Hispanic & 81.6 & 83.8 & $-2.2 \mathrm{pp}$ & 0.02 \\
\hline \multicolumn{5}{|l|}{ By gender } \\
\hline Female & 88.8 & 90.2 & $-1.4 \mathrm{pp}$ & 0.00 \\
\hline Male & 83.3 & 85.7 & $-2.3 \mathrm{pp}$ & 0.00 \\
\hline \multicolumn{5}{|l|}{ Dropout rate } \\
\hline All students & 7.3 & 6.3 & $1.0 \mathrm{pp}$ & 0.00 \\
\hline Economically Disadvantaged & 9.6 & 8.8 & $0.8 \mathrm{pp}$ & 0.00 \\
\hline \multicolumn{5}{|l|}{ By minority status } \\
\hline Asian & 3.8 & 3.3 & $0.5 \mathrm{pp}$ & 0.52 \\
\hline Black & 8.7 & 7.7 & $1.0 \mathrm{pp}$ & 0.01 \\
\hline Hispanic & 12.2 & 11.3 & $1.0 \mathrm{pp}$ & 0.02 \\
\hline \multicolumn{5}{|l|}{ By gender } \\
\hline Female & 5.7 & 5.1 & $0.6 \mathrm{pp}$ & 0.00 \\
\hline Male & 8.9 & 7.5 & $1.4 \mathrm{pp}$ & 0.00 \\
\hline
\end{tabular}

Notes: Sample only includes divisions listing between 272 and 299 calendar days for the academic year.

(1st and 99th percentiles, respectively). Results consistent with the full sample included.

Economically disadvantaged is 1) is eligible for Free/Reduced Meals, or 2) receives TANF, or

3) is eligible for Medicaid, or 4) identified as either Migrant or experiencing Homelessness. 
Table 2. Estimates of pre-Labor Day start (in weeks) on dropout and on-time graduation

\begin{tabular}{|c|c|c|c|c|c|c|c|c|c|c|}
\hline \multirow[t]{2}{*}{ Sample } & \multicolumn{2}{|c|}{ Full sample } & \multicolumn{2}{|c|}{ Male } & \multicolumn{2}{|c|}{ Female } & \multicolumn{2}{|c|}{ Black } & \multicolumn{2}{|c|}{$\begin{array}{l}\text { Economically } \\
\text { Disadvantaged }\end{array}$} \\
\hline & $(1)$ & $(2)$ & $(3)$ & $(4)$ & $(5)$ & $(6)$ & $(7)$ & $(8)$ & $(9)$ & $(10)$ \\
\hline Outcome Variable & \multicolumn{10}{|c|}{ On time graduation rate } \\
\hline \multicolumn{11}{|c|}{ Pre-Labor Day Start (in weeks) } \\
\hline Up to 1 & $\begin{array}{l}-0.131 \\
(0.791)\end{array}$ & $\begin{array}{l}0.298 \\
(0.865)\end{array}$ & $\begin{array}{l}-0.435 \\
(0.980)\end{array}$ & $\begin{array}{l}0.234 \\
(1.029)\end{array}$ & $\begin{array}{l}0.476 \\
(0.774)\end{array}$ & $\begin{array}{l}0.633 \\
(0.994)\end{array}$ & $\begin{array}{l}-0.233 \\
(1.471)\end{array}$ & $\begin{array}{l}0.759 \\
(1.317)\end{array}$ & $\begin{array}{l}-0.688 \\
(1.838)\end{array}$ & $\begin{array}{l}0.787 \\
(1.655)\end{array}$ \\
\hline $1-2$ & $\begin{array}{l}0.379 \\
(0.697)\end{array}$ & $\begin{array}{l}0.708 \\
(0.793)\end{array}$ & $\begin{array}{l}0.526 \\
(0.864)\end{array}$ & $\begin{array}{l}1.102 \\
(0.977)\end{array}$ & $\begin{array}{l}0.667 \\
(0.728)\end{array}$ & $\begin{array}{l}0.726 \\
(0.986)\end{array}$ & $\begin{array}{l}0.298 \\
(1.486)\end{array}$ & $\begin{array}{l}0.885 \\
(1.587)\end{array}$ & $\begin{array}{l}-0.538 \\
(1.463)\end{array}$ & $\begin{array}{l}1.192 \\
(1.559)\end{array}$ \\
\hline $2-3$ & $\begin{array}{l}0.0335 \\
(0.791)\end{array}$ & $\begin{array}{l}0.884 \\
(0.914)\end{array}$ & $\begin{array}{l}-0.148 \\
(0.906)\end{array}$ & $\begin{array}{l}0.762 \\
(1.054)\end{array}$ & $\begin{array}{l}0.718 \\
(0.889)\end{array}$ & $\begin{array}{l}1.452 \\
(1.163)\end{array}$ & $\begin{array}{l}-0.0966 \\
(1.645)\end{array}$ & $\begin{array}{l}0.500 \\
(1.880)\end{array}$ & $\begin{array}{l}-0.546 \\
(1.598)\end{array}$ & $\begin{array}{l}1.399 \\
(1.647)\end{array}$ \\
\hline 3 or greater & $\begin{array}{l}0.924 \\
(0.930)\end{array}$ & $\begin{array}{l}1.856^{*} \\
(1.058)\end{array}$ & $\begin{array}{l}1.244 \\
(1.182)\end{array}$ & $\begin{array}{l}2.278^{*} \\
(1.300)\end{array}$ & $\begin{array}{l}0.882 \\
(1.082)\end{array}$ & $\begin{array}{l}1.756 \\
(1.376)\end{array}$ & $\begin{array}{l}-1.218 \\
(2.126)\end{array}$ & $\begin{array}{l}-0.106 \\
(2.355)\end{array}$ & $\begin{array}{l}0.597 \\
(1.789)\end{array}$ & $\begin{array}{l}2.142 \\
(1.922)\end{array}$ \\
\hline R-Squared & 0.854 & 0.890 & 0.806 & 0.850 & 0.784 & 0.822 & 0.700 & 0.749 & 0.690 & 0.775 \\
\hline Outcome Variable & \multicolumn{10}{|c|}{ out rate } \\
\hline \multicolumn{11}{|c|}{ Pre-Labor Day Start (in weeks) } \\
\hline Up to 1 & $\begin{array}{l}0.194 \\
(0.561)\end{array}$ & $\begin{array}{l}-0.522 \\
(0.695)\end{array}$ & $\begin{array}{l}0.360 \\
(0.773)\end{array}$ & $\begin{array}{l}-0.622 \\
(0.952)\end{array}$ & $\begin{array}{l}-0.113 \\
(0.542)\end{array}$ & $\begin{array}{l}-0.500 \\
(0.619)\end{array}$ & $\begin{array}{l}0.409 \\
(0.744)\end{array}$ & $\begin{array}{l}-0.850 \\
(0.885)\end{array}$ & $\begin{array}{l}1.764 \\
(1.276)\end{array}$ & $\begin{array}{l}-0.123 \\
(1.128)\end{array}$ \\
\hline $1-2$ & $\begin{array}{l}0.210 \\
(0.563)\end{array}$ & $\begin{array}{l}-0.489 \\
(0.716)\end{array}$ & $\begin{array}{l}0.0647 \\
(0.736)\end{array}$ & $\begin{array}{l}-0.900 \\
(0.956)\end{array}$ & $\begin{array}{l}0.135 \\
(0.604)\end{array}$ & $\begin{array}{l}-0.238 \\
(0.740)\end{array}$ & $\begin{array}{l}0.227 \\
(0.795)\end{array}$ & $\begin{array}{l}-0.772 \\
(1.038)\end{array}$ & $\begin{array}{l}1.730 \\
(1.100)\end{array}$ & $\begin{array}{l}-0.271 \\
(1.146)\end{array}$ \\
\hline $2-3$ & $\begin{array}{l}0.0570 \\
(0.628)\end{array}$ & $\begin{array}{l}-0.679 \\
(0.710)\end{array}$ & $\begin{array}{l}0.108 \\
(0.822)\end{array}$ & $\begin{array}{l}-0.649 \\
(0.956)\end{array}$ & $\begin{array}{l}-0.204 \\
(0.649)\end{array}$ & $\begin{array}{l}-0.830 \\
(0.726)\end{array}$ & $\begin{array}{l}0.0232 \\
(1.025)\end{array}$ & $\begin{array}{l}-0.615 \\
(1.247)\end{array}$ & $\begin{array}{l}1.518 \\
(1.298)\end{array}$ & $\begin{array}{l}-0.193 \\
(1.348)\end{array}$ \\
\hline 3 or greater & $\begin{array}{l}-1.201 \\
(0.751)\end{array}$ & $\begin{array}{l}-2.057^{* *} \\
(0.876)\end{array}$ & $\begin{array}{l}-1.512 \\
(1.095)\end{array}$ & $\begin{array}{l}-2.308^{*} \\
(1.303)\end{array}$ & $\begin{array}{l}-0.971 \\
(0.802)\end{array}$ & $\begin{array}{l}-1.821^{*} \\
(0.961)\end{array}$ & $\begin{array}{l}-1.009 \\
(1.364)\end{array}$ & $\begin{array}{l}-1.499 \\
(1.800)\end{array}$ & $\begin{array}{l}-0.161 \\
(1.410)\end{array}$ & $\begin{array}{l}-1.588 \\
(1.600)\end{array}$ \\
\hline R-Squared & 0.763 & 0.816 & 0.724 & 0.780 & 0.657 & 0.719 & 0.576 & 0.644 & 0.593 & 0.684 \\
\hline $\mathrm{n}$ & 1,253 & 1,253 & 1,249 & 1,249 & 1,251 & 1,251 & 1,025 & 1,025 & 1,240 & 1,240 \\
\hline Division Time Linear & $\mathrm{Y}$ & $\mathrm{Y}$ & $\mathrm{Y}$ & $\mathrm{Y}$ & $\mathrm{Y}$ & $\mathrm{Y}$ & $\mathrm{Y}$ & $\mathrm{Y}$ & $\mathrm{Y}$ & $\mathrm{Y}$ \\
\hline Division Time Quadratic & $\mathrm{N}$ & Y & $\mathrm{N}$ & $\mathrm{Y}$ & $\mathrm{N}$ & $\mathrm{Y}$ & $\mathrm{N}$ & Y & $\mathrm{N}$ & $\mathrm{Y}$ \\
\hline
\end{tabular}

Notes: Std Errors in brackets. ${ }^{*} \mathrm{a}<.10,{ }^{* *} \mathrm{a}<.05,{ }^{* * *} \mathrm{a}<.01$. All regressions contain both District and Time FE as well as other covariates described in Equation 1. Errors are clustered at the division level. Sample size is consistent by sample across both outcome variables. For brevity, estimates for Asian and Hispanic samples not shown, although there are no significant effects by start date. 
Table 3. Placebo estimates of Pre-Labor Day start $(t+2)$ on on-time graduation and dropout rate

\begin{tabular}{|c|c|c|c|c|c|}
\hline & $\begin{array}{c}\text { Full } \\
\text { sample }\end{array}$ & Male & Female & Black & $\begin{array}{c}\text { Economically } \\
\text { Disadvantaged }\end{array}$ \\
\hline & $(1)$ & $(2)$ & $(3)$ & $(4)$ & $(5)$ \\
\hline Outcome Variable & \multicolumn{5}{|c|}{ On time graduation rate } \\
\hline \multicolumn{6}{|c|}{ Pre Labor Day Start (in weeks) } \\
\hline \multirow[t]{2}{*}{ Up to 1} & 0.393 & 0.153 & 0.756 & -1.014 & 1.264 \\
\hline & $(0.617)$ & $(0.878)$ & $(0.716)$ & $(1.604)$ & $(2.575)$ \\
\hline \multirow[t]{2}{*}{$1-2$} & 0.205 & -0.258 & 0.743 & -1.192 & 0.544 \\
\hline & $(0.911)$ & $(0.989)$ & $(1.064)$ & $(1.519)$ & $(1.841)$ \\
\hline \multirow[t]{2}{*}{$2-3$} & -0.673 & -0.784 & -0.162 & -0.542 & -1.522 \\
\hline & $(0.902)$ & $(1.031)$ & $(1.055)$ & $(1.566)$ & $(1.972)$ \\
\hline \multirow[t]{2}{*}{3 or greater } & -0.545 & -1.006 & 0.295 & -0.626 & -1.302 \\
\hline & $(0.971)$ & $(1.276)$ & $(1.078)$ & $(1.830)$ & $(2.051)$ \\
\hline $\mathrm{R} 2$ & 0.790 & 0.734 & 0.711 & 0.606 & 0.557 \\
\hline Outcome Variable & \multicolumn{5}{|c|}{ Dropout rate } \\
\hline \multicolumn{6}{|c|}{ Pre Labor Day Start (in weeks) } \\
\hline \multirow[t]{2}{*}{ Up to 1} & 0.312 & 0.212 & 0.313 & 0.0990 & -0.461 \\
\hline & $(0.595)$ & $(0.756)$ & $(0.575)$ & $(1.267)$ & $(1.972)$ \\
\hline \multirow[t]{2}{*}{$1-2$} & 0.149 & 0.0423 & 0.200 & 0.685 & -0.531 \\
\hline & $(0.701)$ & $(0.726)$ & $(0.847)$ & (1.338) & $(1.472)$ \\
\hline \multirow[t]{2}{*}{$2-3$} & 0.644 & 0.209 & 0.755 & 0.443 & 0.564 \\
\hline & $(0.805)$ & $(0.861)$ & $(0.911)$ & (1.338) & (1.627) \\
\hline \multirow[t]{2}{*}{3 or greater } & 1.101 & 1.028 & 0.856 & 1.588 & 0.828 \\
\hline & $(0.870)$ & (1.018) & $(0.968)$ & (1.628) & (1.667) \\
\hline $\mathrm{R} 2$ & 0.665 & 0.625 & 0.552 & 0.450 & 0.455 \\
\hline $\mathrm{n}$ & 1,004 & 1,001 & 1,002 & 832 & 992 \\
\hline
\end{tabular}

Notes: Std Errors in brackets. ${ }^{*} \mathrm{a}<.10,{ }^{* *} \mathrm{a}<.05,{ }^{* * *} \mathrm{a}<.01$. All regressions contain both District and Time FE as well as district level quadratic time trends. Errors are clustered at the division level. Sample size is consistent by sample across both outcome variables. 


\section{Figures}

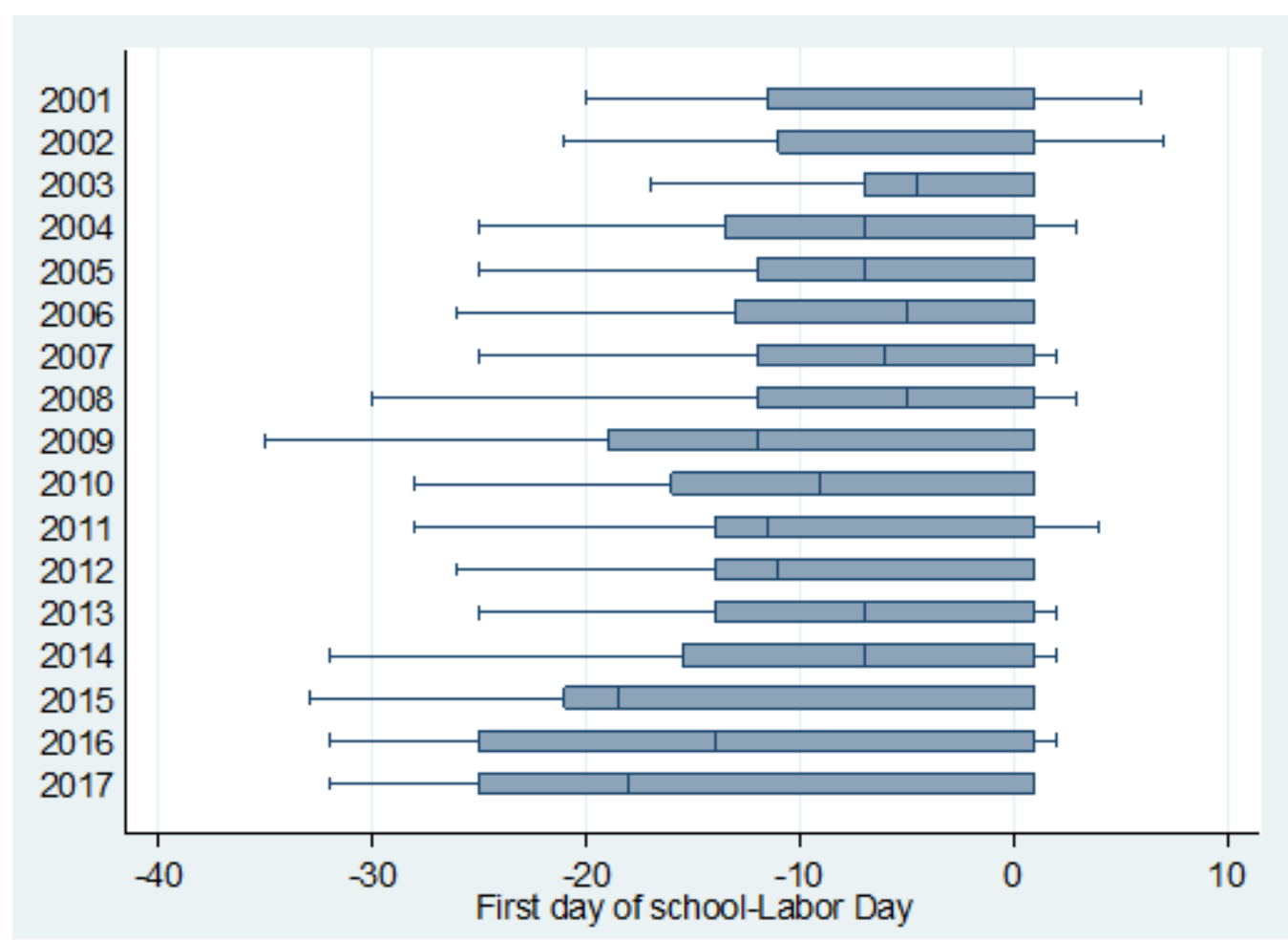

Source: Author analysis of Virginia Department of Education data.

Figure 1: Box plot of school starting dates relative to Labor Day 


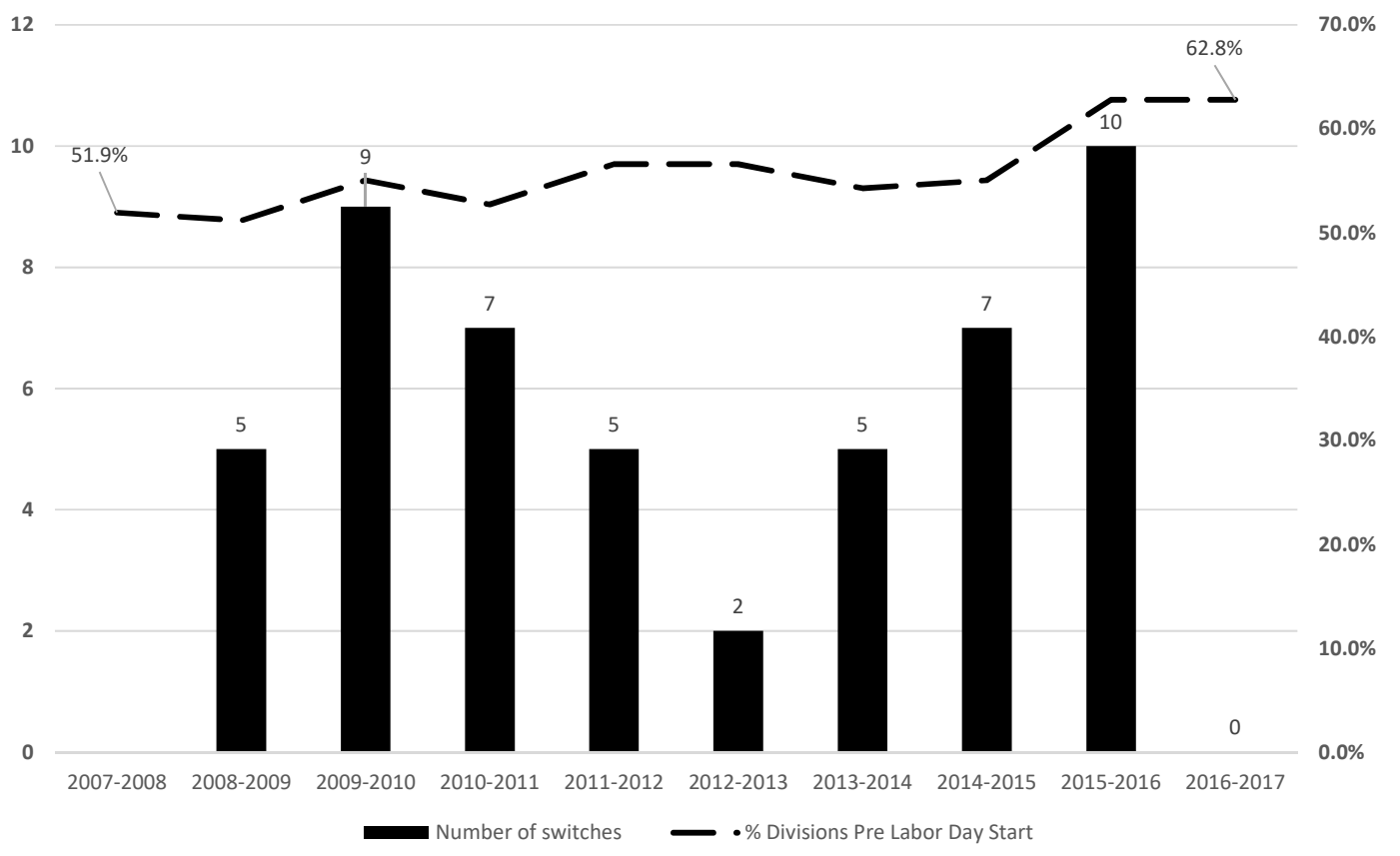

Source: Author analysis of Virginia Department of Education data.

Figure 2: Percentage of Divisions with Pre-Labor Day start and Number of Divisions switching start date relative to Labor Day per Academic Year in Virginia, 2007-2008 to 2016-2017 